\title{
Pension Fund's Corporate and Economic Profiles
}

\author{
Maria Teresa Bianchi ${ }^{1}$, Alessia Nardecchia ${ }^{1} \&$ Filippo Maria Tancioni ${ }^{2}$ \\ ${ }^{1}$ Sapienza, University of Rome, Italy \\ ${ }^{2}$ Rome, Italy \\ Correspondence: Maria Teresa Bianchi, Department of "Diritto ed Economia delle attività produttive", Sapienza \\ University of Rome, Via del Castro Laurenziano n. 9, 00161, Rome, Italy. Tel: 39-067-005-351. E-mail: \\ mtbianchi@bianchiandpartners.it
}

Received: September 4, 2014

Accepted: September 28, 2014

Online Published: October 25, 2014

doi:10.5539/ibr.v7n11p181

URL: http://dx.doi.org/10.5539/ibr.v7n11p181

\begin{abstract}
This survey aims to analyze the relationship between corporate social responsibility and the investment decision of pension funds. In fact, in Italy, the absence of welfare and the lack of social security coverage should encourage the younger generation to join complementary pension form, but this does not always happen for many reasons analyzed by the survey. Companies can play an active role in the new integrated welfare, for example, by ensuring complementary pension form. In this way, however, companies must have a recognition like becoming, if judged socially responsible, target company for the investment of pension funds.

This survey examines, therefore, the relationship among: Pension Funds, CSR, target company, company socially responsible. This would allow companies to play an active role in the welfare and at the same time, to be offset by the loss of cash flow resulting from the obligation to forward to the funds the growing TFR.
\end{abstract}

Keywords: complementary pension form, CSR, pension funds, self-financing, TFR

\section{Introduction}

The following reflections have been stimulated by some typical elements of the Italian context. The first is the TFR and its function as a self-financing component. The second one is the focus on the implementation of pension funds following the obligation, starting from 2007, to forward the severance pay to pension funds and this produce a loss of self-financing that is not adequately compensated. The third element is the fund's ability to select their investments to ensure the best performances to its members. The fourth element is the need to trigger virtuous mechanisms that make possible to restore the level of service expected that, until now, were guaranteed by the welfare state, but now are difficult to keep safe.

From these reflections and analyzes from the performance of the funds and the regulatory changes that affect them in terms of investment choices and from the progressive withdrawal of the state from welfare, it has been suggested the proposed model.

\section{Pension Funds and Corporate Self-Financing Loss}

Pension fund's issue is an old matter that began with the need of change to the social security system from an allocating system to a compounding one (Jessoula M., 2009). Pension fund's establishment in Italy (Note 1) was made by a 1993 law, but till the reform (Note 2), in fact, there wasn't a total subscription that would have been natural, most of all for the younger employees. It has been waiting for a new reform, that enforced enterprises with more than 50 workers to forward the growing TFR (Italian retirement sum), giving the choice to the employees, to Pension Funds or to the INPS (the Italian National Institution for the Social security). The reason of this is caused in economic and business explanations.

First of all it needs to find it in the connection between Pension funds and growing TFR (severance pay). In fact, it's unquestionable that the idea that the part of the growing TFR that goes to a pension fund represents a self-financing loss of money (Note 3) for the enterprises (P. Capaldo, 2013).

Enterprises, big or little as they are, base a great part of their investment capacity on the self-financing resources that they are able to generate.

TFR fund allowance has represented (and still represent for those enterprises who don't have to deposit it in a 
fund) an important self-financing source:

\section{A.F. $=$ Retined Earning + Amortizations + Allowances - Fund Employment}

The highlighted points explain why it has been necessary to create a specific regulation to "enforce" enterprises to transfer this self-financing source without a correct "compensation" (Note 4). For enterprises, that faced this loss in a period near the beginning of the global recession and also with a growing credit crunch (Note 5) due to Basilea 2 rules, the transfer of this money to pension funds has meant:

1) More difficulty to proceed with structural investments;

2) More recalling to short-term debt to cover TFR transfer loss;

3) Overall growing debt load.

Big Enterprises, due to their greater capacity to obtain suitable credits both in quantity and quality and moreover for their greater financial structure, were able to handle this impact, but small enterprises didn't always have the capacity or possibility to change this self-financing source with other similar ones.

Now we may reflect on another point: did the employees who turned their TFR to pension funds, gain any good results? It's hard to say (Note 6).

Obviously employees who are still going to be employed for several years could hope that the recent years income could get better in the future (Note 7). On the other hand, those who deposited TFR only in the recent years didn't have big losses (Note 8). The problem is for employees who in 2007 still had 5/7 years of employment, when yields were damaged.

What was said explains why the enterprises didn't let pension funds starts, by the converting the TFR debt in an outcome with immediate effect, which means in accounting terms, to convert a supposed financial account in a certain one.

The presented survey, however, proves the point that also employees find more yields by depositing their TFR in the enterprises, rather than into the pension funds. This created another cause for reflection on the future of welfare, but first, it is necessary to go to the core of the analysis of the pension fund as an economical player.

\section{Pension Fund's Future: Perspectives for Enterprises and Employees}

The second economic business profile relating to the pension funds is to be found in the fund's operation. These companies in fact have a special mission: to invest the member's assets to generate the greater investment's yields matching risk /yields profiles. Pension Funds are supposed to act by regarding to the interests of their members, whose yields depends on the responsible management of pension fund's assets. This duty should let pension funds to choose appropriate risk-yield profile markets (Harvard Law School, Best Practice for Pension Fund's Investments in Emerging Markets, Sinco). Recently there has been a lot of talking about subscription's drop in pension funds and the consequent decrease in payments, and the increases in advanced payments (Note 9).

All of these elements are the result from the crisis that move to the pension funds and, inevitably, to the subscribers. Technically, pension funds are recognized or non-recognized associations, if this is the legal form, this implies that funds appear to be like companies that produce for domestic consumption (P. Capaldo, 2013). Essentially, this means that upon receipt of the member's shares (the fund's proceeds), costs are incurred for the production.

In this case, it means investing the member's resources to ensure their medium /long-term income to ensure a suitable complementary pension form. Therefore, the fund manager must ask himself some questions:

A) Where to invest the associate's shares to ensure them the best income;

B) In times of great instability it is possible to estimate in advance the amount of the fund's income and the number of members?

The Treasury Department's (Note 10) explanatory memorandum makes it clear that due to the financial market's growth, the collateral pension's reform and the transposition into Italian law of the European regulation pension fund's (Regulaton 2003/41/EC - named IORP Regulation) a revision of the Treasury Minister's Decree n. 703 on November $21^{\text {st }} 1996$, which contains the existing regulation about pension fund's resources criteria and investment restrictions and the rules regarding conflict of interests, is required. The new scheme of ministerial regulation, under public consultation until June $29^{\text {th }}, 2012$ (Note 11) is still not approved.

Over the last two decades finance has changed a lot and it was, therefore, necessary to make changes to the old 
regulation, which excludes emerging markets, commodity and hedge funds from pension fund's portfolios. However the reform does not concern only the pension fund's assets, but also the investment and risk control policies. The opportunity to review the current rules, which are based on quantitative limits and percentage constraints, to support an approach that increases accountability and the ability to better manage and control risks, has been taken into consideration for a long time. The decree's emission, awaited by the industry for several years, has been discussed several times but the legislative process has never completed. Already in 2008, the pension funds were hoping to broaden the range of instruments to invest, and have more freedom in management's decisions. These are opportunities necessarily accompanied by greater fund's accountability in terms of risk control and a more dynamic role in overseeing the work of the pension fund's supervision Commission (Covip). Still in 2008, the opinion of the Sustainable Finance's Forum also highlighted the need to introduce the assessment of social, ethical and environmental issues in the common interest of pension funds and society in the investment policies. This is not only because of ethical considerations, but also related to the general objectives of correct and well-advised management, already present in the "old" 703, as the opinion of the Forum, the ESG (Environment, Social and Governance ) helped to assess the bond's risk-yield profile.

The current regulation provides precise limits for investments - by specifying the types of financial activities in which the fund may invest, by fixing a maximum investment's percentage for each asset class, and by verifying the results using benchmarks - the new decree will be based on greater attention to capacity management and investment processes. The "qualitative" approach to investments will require the technical-Professional tasks within the funds. A prompt risk monitoring is the basis for a more efficient risk management, characterized by professionalism, attention to the processes, and knowledge and management of specific risks.

The Investments in traded tools on regulated markets must be predominant, whereas in the case of OICR (undertakings to invest collective saving), a set of rules that will ensure compliance with the caution criteria, efficiency and effectiveness. Regarding quantitative terms, consultation scheme's article n.5 shows the investment restrictions: no more than $20 \%$ of assets in closed-end funds and hedge, no more than $30 \%$ in financial instruments not traded on regulated markets, no more than 5\% in goods, no more of $30 \%$ of net of hedging currency exposure. Also the possibility of investing in emerging markets, that have been precluded to the Italian pension funds so far, will be discussed. In fact if pension funds can't invest in this markets, the results will be heavy losses in investments opportunities for Italian fund's investors and no resources for emerging countries as well, by generating wastefulness for both (Harvard Law school, Best Practice for Pension Fund's Investments in Emerging Markets, Sinco).

In non-OCSE countries it may be possible to invest but with a limit of $10 \%$ in financial instruments issued by entities belonging to a single group, and $5 \%$ in instruments issued by a single entity.

Concerning to the management of conflict of interests, the draft of article $n .7$ introduces the requirement to make a written a policy to manage conflicts in compliance with the businesses size and complexity, in accordance with the MIFID's principles, Markets in Financial Instruments Directive (Note 12). The text finally gave to Covip the task to establish the cases in which the limits can be made more rigorous or otherwise waived, for example for those funds that demonstrate their know-how for the proper risk-yield monitoring.

The pension fund must define the reference points for the most appropriate fund's risk-yield targets and specify the maximum tolerable risk (the risk budget, the maximum potential loss) with respect to individual investments and overall to the entire portfolio. Therefore, the way pension funds must be given even more responsibility on how to advise, understand and manage the involved risks of their contributors incomes.

\section{Perspective of Ethics}

As evidenced from the analysis and from the needs felt in every sector of company, pension funds could become a tool to "reward" companies that adopt behaviors in line with the principles of corporate social responsibility.

The Decree draft gives many insights in this regard:

1) Amplifies the choice of investment funds;

2) Amplifies the responsibility of the operator;

3) Subordinates decisions to a prior risk analysis, which is essential in any business activity , and is essential in this specific activity.

The pension funds must implement, if not already done, the devices of management control, risk management, internal auditing. Diversifying investments and increasing responsibility require a thorough audit activity at all levels of the company (Note 13). It will also improve the system of governance (Note 14) in which the role of 
the control body and the independence of both supervisory board and managers must be elated.

The pension fund may choose its target investment in companies that can report their "ethical" activity. This implies that in the benchmark, also the variables associated with the CSR of those companies that are the investment target should be taken into consideration.

The literature presents many definitions of corporate social responsibility (Note 15) (Carroll, 1999, p. 268, Jones, 1995 , p. 404, Porter \& Kramer 2006, p. 78; Windsor, 2001, p. 225), that is viewed sometimes as a development of the "care for environment" concept, others times such as "social marketing" (Kotler \& Keller, 2008, p. 29) Some authors claim that this term has not found its way into the language of business and that the concept was better spread in this area with other terms, such as: social responsibility, business ethics, citizenship business (Abratt \& Sacks, 1989, p. 25). The debate on corporate social responsibility is, however, based on the role that companies should play in society by going to define their "positive" behaviors in the social field.

Moreover the CSR has received over the past few times several criticisms, because of its confusion with philanthropy or other activities that lead to greater sustainability, like the environmental care, by using resources of third-parts or of a group of investors. It would be a mistake to consider CSR in this way, because pension fund's choice to forward their investments to companies who have chosen to conduct their business with an eye to reducing environment damages, and thus to the sustainability of our habitat, should represents the desire to minimize negative externalities and emphasize positive ones.

As a result, these companies should be considered as more efficient managers of financial risk, by following "ethical" objectives, they are inclined to avoid imprudent conducts or doubtful business practices. Therefore, investments in companies that conduct their businesses in a social and responsible way, should be considered as better and safer than others, especially in long-term choices. (S. Prakash Sethi, "Investing in Socially Responsible Companies is a Must for Public Pension Funds - Because there is no better alternative").

Where to invest, with respect to this difference, should also be considered (Note 16). The research of ethics target (Note 17) should be reconsidered in the light of the future of social security in Italy, in fact, nowadays the State gradually tends to reduce its presence from this sector, so the thrust of investing in ethical companies can become a "reward" (Note 18) for those companies that adopt socially responsible behavior.

A further element of reflection comes from here: companies, especially small and medium-sized from which the TFR has been "stolen", may become privileged investment objectives, where they demonstrate to be managed according to the principles of so-called corporate social responsibility. So, generally, socially responsible companies become the target of investment funds, in particular, for SMEs to be chosen for being socially responsible becomes to be a compensatory measure of the loss of TFR.

Obviously certainly this is not the place to face these issues, but it is evident that sociability is increasingly perceived as a key element in the management decisions of the company. Sociability is destined to be the litmus test for the targeting of incentive forms, such as the above hypothesized.

\section{Concluding Remarks}

The question that we can ask today, twenty years after the law that established the pension funds, is whether this is a positive experience and that if it will have any future.

Regarding the first aspect I think the cost/benefit analysis may not lead to a clear answer. In fact, if on one hand the experiences of fund performance may not be flattering, on the other hand it should be pointed out that the supplementary pension is the only solution to shift from the "distributive" system to the "capitalization" system.

This leads to the issue of the funds future. Pension funds have been encouraged, even fiscally in such an important way, despite this, their success has not satisfied the expectations, which means that the approach towards the motivation to join these funds should be different. The above mentioned hypothesis of investment in companies, including small/medium sized ones, demonstrating concrete attention to social issues might be, on the one hand, the incentive for companies themselves to invest the sociability. On the other hand it can be a way for the funds to raise their act by becoming a tool to ensure ethical investments, hopefully in the same companies that suffered the loss of self-financing and so would have restored partially the incurred penalties. In fact, the loss of self-financing would be offset from becoming the target of performing investment through the sociability.

\section{References}

Abratt, R., \& Sacks, D. (1989). Perceptions of the Societal Marketing Concept. European Journal of Marketing, 23(6), 25-33. http://dx.doi.org/10.1108/03090569010142640

Capaldo, P. (1968). L'autofinanziamento nell'economica dell'impresa. Giuffrè, Milano. 
Capaldo, P. (2013). L'azienda. Centro di produzione. Giuffrè, Milano.

Carroll, A. B. (1999). Corporate social responsibility: Evolution of a definitional construct. Business and Society. http://dx.doi.org/10.1177/000765039903800303

Cellini, R. (2004). Politica economica - Introduzione ai modelli fondamentali.

El Ghoul, S., Guedhami, O., Kwok, C. C., \& Mishra, D. (2011). Does corporate social responsibility affect the cost of capital? Journal of Banking \& Finance, 35. http://dx.doi.org/10.1016/j.jbankfin.2011.02.007

Jessoula, M. (2009). La politica pensionistica, Il Mulino, Bologna. McGrawn-Hill, Milano.

Jones, T. (1995). Instrumental stakeholder theory: A synthesis of Ethics and economics. Academy of Management Review. http://dx.doi.org/10.5465/amr.1995.9507312924

Kemp, M. H. D., \& Patel, C. C. (2011). Entity-wide risk management for pension funds. A discussion paper, Edimburgh.

Retrieved

from

http://www.actuaries.org.uk/system/files/documents/pdf/ermforpensionfundscombined.pdf

Kotler, P., \& Keller, K. L. (2008). Management Marketing. Editura Teora, Ed. V.

LWP. (n. d). Best Practice for Pension Fund's Investments in Emerging Markets. Retrieved from http://www.law.harvard.edu/programs/lwp/pensions/conferences/pension5_13/Graham-Sinclair-best-practic e-in-emerging-markets.pdf

Margolis, J. D., \& Walsh, J. P. (2003). Misery loves companies: Rethinking social initiatives by business. Administrative Science Quarterly, 48. http://dx.doi.org/10.2307/3556659

McWilliams, A., \& Siegel, D. (2001). Corporate social responsibility: A theory of the firm perspective. Academy of Management Review, 28. http://dx.doi.org/10.5465/amr.2001.4011987

Menz, K. M. (2010). Corporate social responsibility: Is it rewarded by the corporate bond market? A critical note. Journal of Business Ethics, 96. http://dx.doi.org/10.1007/s10551-010-0452-y

Orlitzky, M., Schmidt, F. M., \& Rynes, S. L. (2003). Corporate social and financial performance: A meta-analysis. Organization Studies, 24. http://dx.doi.org/10.1177/0170840603024003910

Porter, M. E., \& Kramer, M. (2006). Strategy and society: The link between competitive advantage and corporate social responsibility. Harvard Business Review. Retrieved from http://hbr.org/2006/12/strategy-and-society-the-link-between-competitive-advantage-and-corporate-social-r esponsibility/ar/1

Sethi, S. P. (2005). Investing in Socially Responsible Companies in a Must for Public Pension Funds - Because There is no Better Alternative. Journal of Business Ethics. http://dx.doi.org/10.1007/s10551-004-5455-0

Sharfman, M. P., \& Fernando, C. S. (2008). Environmental risk management and the cost of capital. Strategic Management Journal, 29. http://dx.doi.org/10.1002/smj.678

United Nations Conference on Trade and Development. (2011). Investment and Enterprise Responsibility Review, New York and Geneva. Retrieved from http://unctad.org/en/docs/diaeed20101_en.pdf

Windsor, D. (2001). The future of corporate social responsibility. International Journal of Organizational Analysis, 9. http://dx.doi.org/10.1108/eb028934

\section{Notes}

Note 1. Pension funds have been established by the Law n. 124 on April 21st, 1993 and following amendments and additions. The purpose of pension funds is to create a form of security for the payment of collateral pension system nearby the public expected one, following proportional criteria. The amount of social security benefits is based on the amount of contributions paid by employees who are signed to the fund and by their compounding financial management.

Note 2. The law n. 296/2006 (on behalf of the Employment Minister Cesare Damiano) brought forward to 2007 what the DL 252/2005 had expected about the Complementary Pension reform, accomplishing a long process started in 1993 and which has had its most decisive moments: in 1997 (the new regulatory about pension funds) and in 2000 (the new taxation about pension savings and the establishment of individual forms of security). From January to June 2007, for employees already hired, or within six months after, for those newly hired, each worker could choose whether to or not to join a collateral pension scheme, by depositing their growing severance 
pay. If they don't express their choose, the severance pay is turned automatically by the employees to the category fund (or in the absence to the residual fund set up by INPS).

Note 3. Self-financing is meant in this context in a financial way, that is when the enterprise is able to cover its total requirement without a total or partial recalling to debt and/or to the owner's equity.

Note 4. Employees should choose the destination of their several pay by considering that the signing in collateral pension funds, even if not compulsory, gives some advantages: employee's contribution (if applicable), the tax claiming of contributions amounts, an advantageous yields and services tax regime and also yields from the financial markets, which in the years following the entry into force of the law were substantially higher than the revaluation of the TFR. Moreover, if the employee choose to deposit his TFR to a collateral pension form, he doesn't lose the possibility to obtain advances to cover their personal and family needs, but the amount of the advance concern, as well as the TFR, also his own contributions, the employee's one and the achieved yields. In 2012 , the banks have cut to Italian companies $€ 44$ billion of loans. This is what emerges from a report by Standard \& Poor's where you expect an ever greater reliance on bond issues by the Italian production to cope with the credit crunch. Currently, the rating agency notes, Italian firms derive $92 \%$ of their short- and long-term banks.

Note 5. In 2012 banks cut off 44 million of euros in credit lines to Italian enterprise. This is what is possible to deduce from a Standard \& Poor's study which expect an ever greater reliance on bond issues by the Italian production enterprises to cope with the credit crunch. Currently, the rating agency notes that Italian enterprises draw $92 \%$ of their short and long-term needs from banks.

Note 6. COVIP - Report for the year 2012. To date, the employees enrolled in collateral pension funds are about 5.8 million, a quarter of the total employed. The percentage is reduced to one-fifth if we consider only those employees who in 2012 made payments of contributions. In recent years, it has been an increase of subscriptions between different instruments of social security: it is concentrated in the individual plans of insurance type, which are more expensive on the average and don't consider the contributions paid by the employers, and instead it has stagnated in forms for collective membership, which benefit from contributions paid by the employers and are, on the average, less burdensome.

Table 1. 2012 Italian complementary pensions: summary data

\begin{tabular}{lccccc}
\hline Amounts in millions of Euros & & & & \\
& Funds & & Signed $^{(1)}$ & \multicolumn{2}{c}{ Resources allocated to performance $^{(2)}$} \\
\cline { 3 - 6 } & & Numbers & var. \% $2012 / 2011$ & Amounts & var \% 2012/2011 \\
\hline Negotiating Pension funds & 39 & 1.969 .771 & $-1,2$ & 30.174 & 19,4 \\
Open-ended Funds & 59 & 913.913 & 3,7 & 10.078 & 20,5 \\
Old Pension Funds & 361 & 659.920 & $-0,7$ & 48.010 & 9,6 \\
"New" PIP $^{(3)}$ & 76 & 1.777 .024 & 22,4 & 9.813 & 36,4 \\
TOTAL $^{(4)}$ & $\mathbf{5 3 6}$ & $\mathbf{5 . 3 5 6 . 9 2 9}$ & $\mathbf{6 , 5}$ & $\mathbf{9 8 . 1 2 8}$ & $\mathbf{2 5 , 9}$ \\
"Old" PIP $^{(5)}$ & & $\mathbf{5 3 4 . 8 1 6}$ & & 6.273 & 4,6 \\
OVERALL TOTAL $^{(4)(6)}$ & & $\mathbf{5 . 8 2 8 . 6 7 4}$ & $\mathbf{5 , 3}$ & $\mathbf{1 0 4 . 4 0 1}$ & $\mathbf{1 5 , 1}$ \\
\hline
\end{tabular}

${ }^{(1)}$ Includes members who have not made payments in the current year and the so-called deferred. Retirees are excluded.

${ }^{(2)}$ Total resources allocated to performance. Include the net assets available for benefits (ANDP) for pension funds and open-ended ones, for old funds that are legal subjects; the assets of the target or the mathematical reserves for existing funds that are not legal subjects; mathematical reserves constituted to members by insurance companies for funds managed by existing insurance policies; the mathematical reserves for the PIP traditional type, and the shares value outstanding for the unit linked PIP.

${ }^{(3)}$ PIP following Legal Decree n. 252/2005.

${ }^{(4)}$ FONDINPS in included in the total.

${ }^{(5)} \mathrm{PIP}$ that are included before the 2005 reform and that are not following the Legal Decree n. 252/2005.

${ }^{(6)}$ Duplication due to members signed in new and old PIP are excluded. 
Note 7. COVIP - Report for the year 2012. Since the beginning of 2000 to the end of 2012, the cumulative pension fund's yield has been $41.1 \%$, lower than the $43.6 \%$ obtained from the TFR during the same period. At the same time the open pension funds, which are mark out by an average higher exposure to equities, they earn just $12.4 \%$.

Note 8. In 2012 the management results of collateral pension forms have been higher than the rate of appreciation of the TFR; the latter, which has had a decrease from the previous year, gained a $2.9 \%$ rate. All types of new establishment's collateral pension forms have registered an average yield between 8 and 9 percent, benefiting from the financial market's positive trend: the result was a rate of 8.2 for pension funds, a rate of ' 8,9 for class III unit-linked PIP products (Individual pension plans) and a rate of 9.1 percent for open-ended funds. Exception is for class I PIP separate management, which have had gained a rate of 3.8 percent (compare to glossary, under "separate management" and "Unit-linked"). For each investment line, the best results were achieved by the pension with a higher exposure to equities, supported by the world equity market's trend; the global equities rate in local currency, calculated considering dividends, grew by a rate of 15.7 percent. The pension fund's equity and balanced sections have gained, respectively, a rate of 11.4 and 9.2 percent. In the open-ended funds yield was 10.8 percent for the equity investment guidelines and 10 percent for those balanced; in the same PIP's lines yields were equal, respectively, 10.8 and 7.4 percent. In the pension forms with a predominance of investments in bonds yields were lower, but still appreciable in a context in which the relevant markets showed powerful recoveries in the prices of bonds. The government bond's aggregate index in the euro area, which includes the composing coupon 2012 Report, gained to a rate of 8,7 percent concerning maturities between 3 and 5 years, close to the average duration of pension's bond's portfolios (about 3-4 years).

Table 2. Pension funds and "new" PIP yields

\begin{tabular}{|c|c|c|c|c|c|c|c|c|}
\hline \multicolumn{9}{|l|}{ (Percentage values) } \\
\hline & 2005 & 2006 & 2007 & 2008 & 2009 & 2010 & 2011 & 2012 \\
\hline Negotiating Pension Funds & 7,5 & 3,8 & 2,1 & $-6,3$ & 8,5 & 3,0 & 0,1 & 8,2 \\
\hline One-branch Funds & 8,3 & 3,7 & 1,4 & - & - & - & - & - \\
\hline \multicolumn{9}{|l|}{ Multi-branch Funds } \\
\hline Granted & - & - & - & 3,1 & 4,6 & 0,2 & $-0,5$ & 7,7 \\
\hline Pure bond & 2,1 & 2,6 & 2,2 & 1,6 & 2,9 & 0,4 & 1,7 & 3 \\
\hline Mixed bond & 6,9 & 2,7 & 2,1 & $-3,9$ & 8,1 & 3,6 & 1,1 & 8,1 \\
\hline Balanced & 7,9 & 5,6 & 2,4 & $-9,4$ & 10,4 & 3,6 & $-0,6$ & 9,2 \\
\hline Equity & 14,9 & 8,2 & 1,3 & $-24,5$ & 16,1 & 6,2 & $-3,0$ & 11,4 \\
\hline Open-ended Funds & 11,5 & 2,4 & $-0,4$ & -14 & 11,3 & 4,2 & $-2,4$ & 9,1 \\
\hline Granted & 2,9 & 1,0 & 1,9 & 1,9 & 4,8 & 0,7 & $-0,3$ & 6,6 \\
\hline Pure bond & 3,3 & $-0,2$ & 1,6 & 4,9 & 4,0 & 1,0 & 1,0 & 6,4 \\
\hline Mixed bond & 6,4 & 1,0 & 0,3 & $-2,2$ & 6,7 & 2,6 & 0,4 & 8,0 \\
\hline Balanced & 11,4 & 2,4 & $-0,3$ & $-14,1$ & 12,5 & 4,7 & $-2,3$ & 10,0 \\
\hline Equity & 16,2 & 3,7 & $-1,6$ & $-27,6$ & 17,7 & 7,2 & $-5,3$ & 10,8 \\
\hline \multicolumn{9}{|l|}{ "New" PIP } \\
\hline Separate management & & & & 3,5 & 3,5 & 3,8 & 3,5 & 3,8 \\
\hline Unit-linked & & & & $-24,9$ & 16,3 & 5,2 & $-5,7$ & 8,9 \\
\hline Bond & & & & 2,7 & 4,1 & 0,7 & $, 0,9$ & 5,3 \\
\hline Balanced & & & & $-9,3$ & 8,8 & 2,8 & $-4,0$ & 7,4 \\
\hline Equity & & & & $-36,5$ & 23,1 & 7,5 & $-8,8$ & 10,8 \\
\hline \multicolumn{9}{|l|}{ To remember: } \\
\hline TFR appreciation & 2,6 & 2,4 & 3,1 & 2,7 & 2,0 & 2,6 & 3,5 & 2,9 \\
\hline
\end{tabular}


Note 9. Covip - 2012 Report. www.covip.it; Convention entitled "collateral welfare": a Country resource" - July $15^{\text {th }} 2013$, Milan.

Note 10. MEF - Treasury Department - IV management - IV Office, Consultation about the ministerial draft regulation laying down rules about pension fund's criteria and investment limits of resources and rules regarding conflicts of interest. May $29^{\text {th }}, 2012$

Note 11. Implementation scheme of Art. 6, paragraph 5-bis of Legislative Decree n. 252 of 2005 for the investment limit's revision laid down by the DM 703/96 laying down detailed rules on the criteria and investment limits of the pension fund's resources and the rules regarding interest's conflicts, May $29^{\text {th }}, 2012$.

Note 12. Clarified in the Explanatory Report on the ministerial regulation draft implementing Article n.6, paragraph 5-bis of the Legislative Decree n. 252 on the December $5^{\text {th }} 2005$ laying down rules on the criteria and investment limits of the pension fund's resources and the rules regarding conflict of interests. MEF - Treasury Department - Management IV - Office IV. May 29 2012.

Note 13. Regarding the COVIP, with resolution of March16th 2012, particular attention has been paid to the organizational structure of the supplementary pension schemes, with regard to the duties and responsibilities of the entities and organizational units involved in the governance of pension funds. In particular see the art. 5:06 of the foregoing Resolution. According to the Bank of Italy should be in Negotiating Pension Funds, on the one hand, raise the overall level of professionalism of the board, also through training and updating to ensure the appropriateness of the expertise achieved in practice; secondly, to clarify the powers of the Board, the fund manager and the person responsible for the internal audit function, eliminating the duplication of existing functions and potential conflicts of interest. In the collective membership and mixed FPA would be appropriated, on the one hand, introduce a better distinction of supervisory tasks between the fund manager and the supervisory body; for the other, to provide the most effective mechanisms for the representation of beneficiaries in the composition of the latter. For both categories of FP, finally, it would be desirable to adopt effective measures for the management of conflicts of interest, such as obligations to abstain from deliberations of the person concerned and the annulment of those decisions where they have been taken in breach of the obligations.

Note 14. Resolution of 16 March 2012, the COVIP, cit.

Note 15. CSR can be divided into "internal" and "external" depending on the beneficiaries and stakeholders involved in the social enterprises. Internal corporate social responsibility refers to the human resources of companies and it is a prerequisite and a test of honesty for its extension to the external environment. The field of its implementation requires respect for workers' rights, care for their health and safety, their education and open communication within the company. (Corporate Social Responsibility in Greece - Issues and Prospects, the Philip Morris Institute, 2000, p. 10) CSR is rapidly becoming a global expectation that requires a comprehensive strategic feedback. In the 21 st century, companies are required to do the following:

- Demonstrate their commitment to the values of society and their contribution to the social, environmental and economic objectives through actions;

- Share the benefits of company activities with key stakeholders and the shareholder as well;

- Doing well by doing good will reassure stakeholders that the new behavior will let survive good intentions (Georgeta Grigore, 2008), Corporate Social Responsibility - Business, Society and Stakeholders towards a Sustainable and Competitive Enterprise vol. of the International Conference-European Union's History, Culture and Citizenship, Publishing House of the University of Pitesti, p. 28).

Note 16. The ethical rating is seen as a new market opportunity so that an increasing number of companies that consider the issues related to sustainability as the effective strategic tools to differentiate themselves from competitors and gain a sustainable competitive advantage. However, it is often very difficult to find information about the ethical management of a company as this conflicts with a requirement of internal secrecy on the part of firms. In this context, it is, therefore, required the involvement of independent actors with the task of judging the actual behavior of a sustainable society in an impartial manner, signaling to investors the most virtuous and deserving of catalyzing the resources of ethical finance. The ethical rating agencies rely for their work not only documents prepared for this purpose by businesses to demonstrate their commitment to sustainability issues, such as environmental or social reports and corporate websites (internal sources), but also the specialized press, the trade unions and pressure groups (external sources), which provide greater impartiality of the information. Currently, considering the United States and Europe, including the company's most important ethical rating include: AEI Standard Ethics, Axia, and Capital Partners, EIRIS, KLD , SAM and Vigeo.

Note 17. Despite the increase of corporate's social activities, the question if CSR improves the financial 
performance enterprise (CFP) remains largely unanswered. In fact, while the results of the Orlitzky et al. analysis (2003) suggest a positive relationship between CSR and financial performance; in the literature there are different opinions about it. For example, Margolis and Walsh (2003) show that 48 out of 109 studies reviewed did not find a clear relationship between CSR and financial performance, as it is also found in studies made by McWilliams and Siegel in 2001, which led to further discussion on how financial markets perceive socially responsible companies. El Ghoul et al. (2011) address this issue by examining the CSR impact on the cost of business financing, pointing out that CSR is associated with a lower cost of equity. Another study that confirms the positive relationship, albeit weak, between CSR and bond spreads in Europe was made by Menz (2010). Sharfman and Fernando (2008) Finally, note that companies involved in the social bond yields get more favorable.

Note 18. In Italy, according to a recent survey of European Investment Agency Standard Ethics, the returns on the stock exchange of the largest companies listed are linked to their ethical rating, which means the performance of companies in environmental, social and governance of the company. Of the European Research looked at a sample of 40 companies listed on the Sp- MIB40 in the period from July 2002 to June 2006. The final results show that firms with a rating higher ethical fail to achieve better financial performance. The earliest recorded an increase of capitalization of $53 \%$ which is a figure that exceeds the average performance of the index that is equal to $37 \%$. Macroscopically, it is noted that there is a correlation in the medium term, including the performance of companies and their propensity to adopt instruments of social responsibility and good governance, according to the OECD Guidelines of the Ordinance. N.U and U.E. Ilsole24ore July 7 2006.n.184 p. 35 .

\section{Copyrights}

Copyright for this article is retained by the author(s), with first publication rights granted to the journal.

This is an open-access article distributed under the terms and conditions of the Creative Commons Attribution license (http://creativecommons.org/licenses/by/3.0/). 